\title{
PERLINDUNGAN HUKUM TERHADAP DATA PRIBADI DALAM INDUSTRI FINANCIAL TECHNOLOGY
}

\author{
Elvira Fitriyani Pakpahan \\ Fakultas Hukum, Universitas Prima Indonesia \\ email: elvirapakpahan@unprimdn.ac.id \\ Lionel Ricky Chandra \\ Fakultas Hukum, Universitas Prima Indonesia \\ email: lionelchandra03@gmail.com \\ Ananta Aria Dewa \\ Fakultas Hukum, Universitas Prima Indonesia \\ email: ananta1146@gmail.com
}

disampaikan 08/03/2020 - di-review 01/06/2020 - diterima 03/12/2020

DOI: $10.25123 /$ vej.3778

\begin{abstract}
It came to the author's attention that personal data collected or appropriated in the course of FinTech industry especially those that related to FinTech Peer to Peer Lending services are prone to misuse. The author, after perusing the prevailing laws regarding FinTech industry, concludes that a well-functioning system of rules has been put in place to regulate this industry. However, what is lacking is sufficient guarantee or protection of consumer's personal data. Available is the option to use a weak (administrative, civil or penal) sanction against alleged misuse or misappropriation of personal data. To enhance better legal protection, the author suggests, that the government issue a special law on personal data protection, including establishing a a special governmental supervisory body to that purpose.
\end{abstract}

Keywords:

personal data, FinTech, peer to peer lending, consumer

\begin{abstract}
Abstrak
Penulis mengamati banyaknya penyalahgunaan data pribadi dalam industri FinTech, terutama pada FinTech Peer to Peer Lending. Berdasarkan penelurusan peraturan perundang-undangan ditemukan bahwa pemerintah sudah mengatur industri FinTech dengan baik, sekalipun perlindungan yang diberikan terhadap pengguna (konsumen) ternyata belum lengkap atau sempurna. Masih ditemukan ada kelemahan dalam pemberian sanksi (administrasi, pidana dan perdata) bagi para pelanggar hukum. Untuk meningkatkan perlindungan, diperlukan adanya Undang-Undang Perlindungan Data Pribadi maupun lembaga khusus yang mengawasi perlindungan data pribadi tersebut.
\end{abstract}

Kata kunci:

data pribadi, FinTech, peer to peer lending, konsumen 


\section{Pendahuluan}

Dewasa ini, revolusi industri 4.0 telah mengakibatkan perubahan yang cepat di dunia yang kita tempati dan perkembangan teknologi digital sudah berlangsung dengan pesat di berbagai belahan dunia, tak terkecuali juga di Indonesia. ${ }^{1}$ Adanya kemajuan teknologi digital, memberi dampak bagi manusia dari dua sisi, sisi positifnya menghadirkan kemudahan di tengah-tengah masyarakat, namun sisi negatifnya adalah munculnya berbagai permasalahan seiring dengan berjalannya waktu. Sektor ekonomi juga ikut terkena dampak dari dua sisi perkembangan teknologi digital ini, salah satunya dengan munculnya Financial Technology atau dapat disingkat menjadi Fintech yang berarti Teknologi Finansial.

Menurut keterangan yang diberikan oleh Otoritas Jasa Keuangan atau 0JK, dengan segmentasi pasar pada sektor finansial yang kian bertambah luas, industri Fintech atau teknologi finansial di Indonesia telah berkembang dengan pesat sekitar dua tahun belakangan ini. ${ }^{2}$ Namun, meski perkembangan Fintech di Indonesia sudah dikatakan pesat selama beberapa tahun terakhir ini, perlu diketahui bahwa masih banyak orang Indonesia yang masih belum memahami atau mengerti betul apa dan bagaimana Fintech tersebut, yang Fintech sendiri merupakan kombinasi antara sistem keuangan dan teknologi digital yang membuat cara pandang manusia dalam prosesnya menjadi lebih moderen terhadap sistem keuangan dengan adanya perkembangan teknologi tersebut. ${ }^{3}$

Pada prosesnya, sejumlah permasalahan ikut muncul dengan berkembangnya Fintech di Indonesia. Permasalahan tersebut berkaitan dengan perusahaan Fintech dan konsumen yang menggunakan layanan Fintech tersebut. Salah satu permasalahan hukum yang muncul pada industri Fintech ini adalah tentang bagaimana perlindungan terhadap data pribadi konsumen. Hal ini menjadi sangat penting, sebab diketahui bahwa dalam industri Fintech terutama

1 Sri Adiningsih, Transformasi Ekonomi Berbasis Digital di Indonesia, Gramedia Pustaka Utama, Jakarta: 2019, hlm., 2.

2 Aris Wasita, "OJK: industri "fintech" di Indonesia berkembang pesat", 2019, (https://www.antaranews.com/berita/1030232/ojk-industri-fintech-di-indonesiaberkembang-pesat), diakses pada $22 / 11 / 2019$.

3 Sri Adiningsih, Supra No. 1, hlm., 88. 
pada P2P (peer-to-peer) Lending, rupanya masih banyak terjadi data pribadi konsumen yang disalahgunakan, seperti akses terhadap kontak telepon milik konsumen. ${ }^{4}$

Melihat maraknya masalah yang timbul pada Industri Keuangan Non-Bank (IKNB) termasuk Fintech, mendorong OJK untuk terus memacu reformasi pada sektor ini. Sebagaimana dikutip dari Majalah Edukasi Konsumen Edisi Maret 2020 yang diterbitkan $\mathrm{OJK}$, disebutkan: “...maraknya fintech peer to peer lending ilegal ini mendorong OJK mempercepat reformasi ini guna mempertahankan kredibilitas IKNB."5 Dengan demikian, bisa dikatakan bahwa berbagai masalah yang timbul seiring perkembangan industri Fintech termasuk mengkhawatirkan apabila tidak segera diatasi dengan baik.

Terkait dengan hak-hak yang dimiliki konsumen, merujuk pada Pasal 4 Undang-Undang Perlindungan Konsumen Nomor 8 Tahun 1999 (selanjutnya akan disebut dengan UU Perlindungan Konsumen), dapat diketahui bahwa setiap konsumen memiliki berbagai hak yang harus dipenuhi, dan berdasarkan Pasal UU Perlindungan Konsumen tersebut kemudian dapat dipahami bahwa perlindungan data pribadi konsumen dalam industri Fintech menjadi sangat penting demi menjaga hak-hak yang dimiliki oleh konsumen yang bersangkutan. Pada prinsipnya, setiap perusahaan Fintech yang tidak mendaftar atau belum mendapat izin dari pemerintah dalam hal ini Otoritas Jasa Keuangan (OJK) atau Bank Indonesia (BI), sudah pasti legalitas dari perusahaan Fintech tersebut akan dipertanyakan dan dicurigai sebagai perusahaan Fintech yang ilegal. Hal ini juga akan berdampak buruk pada melemahnya pengawasan dan perlindungan terhadap konsumen yang menggunakan layanan dari perusahaan Fintech tersebut. Sehingga berbagai pelanggaran dapat terjadi dan dilakukan oleh perusahaan Fintech yang ilegal tersebut. Termasuk perihal pelanggaran data pribadi

4 Yanurisa Ananta, "Fintech Salahgunakan Data Konsumen, Siap-siap Kena Denda", 2019, (https://www.cnbcindonesia.com/tech/20190705141712-37-82978/fintech-salahgunakandata-konsumen-siap-siap-kena-denda), diakses pada 22/11/2019.

5 Otoritas Jasa Keuangan, "Majalah Edukasi Konsumen Edisi Maret 2020", 2020, hlm 3, (https://sikapiuangmu.ojk.go.id/FrontEnd/CMS/DetailMateri/492). 
konsumen yang salah satu bentuknya adalah pencurian terhadap data pribadi milik konsumen. ${ }^{6}$

Oleh karena itu, saat ini regulasi dalam industri Fintech dipandang sebagai hal yang sangat krusial mengingat begitu banyak dan beragam permasalahan hukum yang sudah timbul dan tentu hal ini juga dilakukan agar pencegahan dan penanggulangan terhadap masalah tersebut dapat dilakukan. Aturan-aturan yang terkait dengan perlindungan data pribadi khususnya data pribadi dalam sistem elektronik terdapat pada Undang-Undang Informasi dan Transaksi Elektronik Nomor 11 Tahun 2008 (selanjutnya akan disebut UU ITE) dan telah lebih lanjut diatur dalam Peraturan Menteri Komunikasi dan Informatika Republik Indonesia Nomor 20 Tahun 2016 tentang Perlindungan Data Pribadi dalam Sistem Elektronik. Kemudian, aturan tentang penyelenggaraan Fintech pada awalnya diatur pada Peraturan Bank Indonesia Nomor 18/40/PBI/2016 tentang Penyelenggaraan Pemrosesan Transaksi Pembayaran. Setelah peraturan tersebut muncul, terdapat aturan baru soal Fintech yang khususnya mengatur soal P2P Lending terdapat pada Peraturan Otoritas Jasa Keuangan (POJK) Nomor 77/POJK.01/2016 tentang Layanan Pinjam Meminjam Uang Berbasis Teknologi Informasi. Demikian pada tahun berikutnya muncul lagi peraturan-peraturan lain yang terkait soal penyelenggaran Fintech di Indonesia seperti: Peraturan Bank Indonesia Nomor 19/12/PBI/2017 tentang Penyelenggaraan Teknologi Finansial dan Surat Edaran Otoritas Jasa Keuangan Nomor 18/SEOJK.02/17 tentang Tata Kelola dan Risiko Teknologi Informasi pada Layanan Pinjam Meminjam Uang Berbasis Teknologi Informasi.

Peraturan terbaru yang telah diterbitkan pemerintah pada November 2019, yakni Peraturan Pemerintah Republik Indonesia Nomor 80 Tahun 2019 tentang Perdagangan Melalui Sistem Elektronik sekiranya juga dapat menjadi

6 Mochamad Januar Rizki, “Ragam Masalah Hukum Fintech yang Jadi Sorotan di 2018”, 2018, (https://www.hukumonline.com/berita/baca/lt5c1c9d0759592/ragam-masalah-hukumfintech-yang-jadi-sorotan-di-2018/), diakses pada 22/11/2019. 
acuan legalitas bagi para pelaku industri Fintech. ${ }^{7}$ Namun untuk Undang-Undang yang secara khusus mengatur tentang perlindungan data pribadi, sampai saat ini masih belum ada dan masih berupa Rancangan Undang-Undang tentang Perlindungan Data Pribadi (selanjutnya akan disebut dengan RUU Perlindungan Data Pribadi). Perlu diketahui bahwa RUU Perlindungan Data Pribadi telah mengalami proses panjang dimulai pada tahun 2012 yang pada saat itu masih berupa analisis hukum tentang Perlindungan Data Pribadi menuju pembentukan peraturan Perlindungan Data Pribadi hingga akhirnya menjadi RUU Perlindungan Data Pribadi yang juga merupakan prioritas untuk dibahas Dewan Perwakilan Rakyat di tahun $2019 .{ }^{8}$

Berdasarkan uraian latar belakang di atas, penelitian akan fokus pada pokok pembahasan masalah yaitu: Bagaimana perlindungan hukum terhadap data pribadi dalam industri Financial Technology dan analisis kritis terhadap peraturan perundang-undangan yang diperlukan Indonesia untuk mengatur perlindungan data pribadi dalam industri Fintech.

Metode penelitian yang akan digunakan dalam artikel ini adalah berupa metode penelitian hukum normatif, yaitu penelitian hukum dilakukan dari perspektif internal dengan objek penelitiannya adalah norma hukum. ${ }^{9}$ Penelitian hukum normatif memiliki fungsi untuk memberi argumentasi yuridis ketika terjadi kekosongan, kekaburan dan konflik norma. ${ }^{10}$ Penelitan hukum normatif umumnya dilakukan dengan meneliti sumber data sekunder berupa bahan hukum primer, bahan hukum sekunder dan bahan hukum tersier. Teknik pengumpulan data yang digunakan dalam penelitian ini adalah studi kepustakaan. Dalam penelitian ini, sumber data sekunder tersebut adalah bahan hukum primer seperti peraturan perundangan-undangan, bahan hukum sekunder seperti buku-buku,

7 Hendra Friana, "Jokowi Teken PP 80/2019 tentang Perdagangan Elektronik", 2019, (https://tirto.id/jokowi-teken-pp-802019-tentang-perdagangan-elektronik-emQg), diakses pada $22 / 11 / 2019$.

8 Pratiwi Agustin, "Rancangan Undang-Undang Perlindungan Data Pribadi", 2019, (https://aptika.kominfo.go.id/2019/09/rancangan-undang-undang-perlindungan-datapribadi/)

9 I Made Pasek Diantha, Metodologi Penelitian Hukum Normatif Dalam Justifikasi Teori Hukum, Prenada Media Group, Jakarta: cet 2, Maret 2017, hlm. 12.

10 Id. 
jurnal ilmiah, serta sumber pendukung lainnya. Data sekunder berupa bahanbahan hukum di atas yang selanjutnya akan dianalisis lagi oleh penulis dengan cara deskriptif analitis.

\section{Pembahasan}

\section{Perlindungan Hukum Terhadap Data Pribadi}

Sebelum penulis membahas lebih lanjut tentang bagaimana perlindungan hukum terhadap data pribadi dalam industri Fintech, sekiranya perlu dipahami terlebih dahulu hal-hal penting yang berkaitan dengan perlindungan hukum terhadap data pribadi. Bila dicermati pada Pasal 28 G ayat (1) Undang-Undang Dasar Negara Republik Indonesia Tahun 1945, ada disebutkan bahwa "Setiap orang berhak atas perlindungan diri pribadi, keluarga, kehormatan, martabat dan harta benda yang di bawah kekuasaannya, serta berhak atas rasa aman dan perlindungan dari ancaman ketakutan untuk berbuat atau tidak berbuat sesuatu yang merupakan hak asasi." Secara tersirat, sesungguhnya ayat di atas bermakna bahwa jaminan terhadap hak atas privasi sangatlah penting, sebab hak privasi punya keterkaitan erat dengan perlindungan diri dan rasa aman bagi setiap orang, tanpa terkecuali.

Sehingga data pribadi juga termasuk dalam hak atas privasi yang sudah seharusnya dijaga dan dilindungi. Sesungguhnya perlindungan privasi dan data pribadi tidaklah sama dalam hal pengertian dan ruang lingkupnya, perbedaan terletak pada pengertian dan konteks privasi yang sebetulnya lebih luas dan abstrak bila dibandingkan dengan perlindungan data pribadi, yakni hak untuk tidak diganggu (non-interference), akses terbatas (limited accessibility) atau kendali atas informasi pribadi (information control), lain halnya dengan perlindungan data pribadi yang secara khusus mengatur tentang bagaimana undang-undang melindungi, bagaimana data pribadi dikumpulkan, didaftarkan, disimpan, dieksploitasi, dan disebarluaskan. ${ }^{11}$ Adanya pengaturan perlindungan data pribadi menjadi kunci penting dari permasalahan bisnis dan

11 Sinta Dewi Rosadi, Cyber Law: Aspek Data Privasi Menurut Hukum Internasional, Regional, dan Nasional, Refika Aditama, Bandung, 2015, hlm., 1. 
ekonomi di bidang bisnis informasi intensif di era modern sekarang ini. ${ }^{12}$ Selain itu, perlindungan data merupakan HAM (Hak Asasi Manusia) yang fundamental dan sejumlah negara juga sudah mengakui perlindungan data sebagai hak konstitusional. ${ }^{13}$

Dalam artikel ini, pembahasan data pribadi yang dimaksud adalah data pribadi dalam sistem elektronik. Pada dasarnya, tidak ada pengaturan khusus tentang perlindungan data pribadi pada UU ITE. Hanya pada Pasal 26 UU ITE saja yang secara eksplisit memuat ketentuan tentang data pribadi. Beberapa Pasal lain pada UU ITE memang memuat ketentuan tentang data pribadi, akan tetapi hanya secara implisit atau tersirat. Coba perhatikan bunyi Pasal 26 UU ITE berikut, yakni pada:

- Pasal 26 Ayat (1) UU ITE menyebutkan, "Kecuali ditentukan lain oleh peraturan perundang-undangan, penggunaan setiap informasi melalui media elektronik yang menyangkut data pribadi seseorang harus dilakukan atas persetujuan Orang yang bersangkutan."

- Pasal 26 Ayat (2) UU ITE menyebutkan, "Setiap Orang yang dilanggar haknya sebagaimana dimaksud pada ayat (1) dapat mengajukan gugatan atas kerugian yang ditimbulkan berdasarkan Undang-Undang ini."

Berdasarkan bunyi Pasal di atas, dapat diketahui jika seseorang menggunakan informasi-informasi orang lain melalui media elektronik tanpa terlebih dulu meminta atau mendapatkan persetujuan dari pemilik yang bersangkutan, maka orang tersebut dapat digugat atas kerugian yang diperbuatnya, pengecualian hanya berlaku kalau ada ketentuan lain berdasarkan peraturan perundang-undangan.

Masalah keamanan data pribadi tidak dapat dianggap sepele, sebab data pribadi sering menjadi sasaran empuk para pelaku cyber crime atau kejahatan siber yang tidak bertanggung jawab. Namun sebelum lebih lanjut membahas tentang data pribadi. pertama-tama sekiranya perlu diketahui apa saja definisi dari data pribadi.

\footnotetext{
12 Sinta Dewi, Konsep Perlindungan Hukum Atas Privasi Dan Data Pribadi Dikaitkan Dengan Penggunaan Cloud Computing Di Indonesia, Yustisia Jurnal Hukum, Vol 5, No. 1, 2016, hlm., 27.

13 Id., hlm., 26.
} 
Pada Pasal 1 angka 27 Peraturan Pemerintah Republik Indonesia Nomor 82 Tahun 2012 memberikan definisi data pribadi sebagai berikut: "data pribadi adalah data perseorangan tertentu yang disimpan, dirawat, dan dijaga kebenaran serta dilindungi kerahasiaannya." Demikian pada Pasal 1 angka 1 Peraturan Menteri Komunikasi dan Informatika Nomor 20 Tahun 2016, juga memberikan definisi data pribadi sebagai berikut: "data pribadi adalah data perseorangan tertentu yang disimpan, dirawat, dan dijaga kebenaran serta dilindungi kerahasiaannya." Merujuk pada Pasal 1 angka 2 Peraturan Menteri Komunikasi dan Informatika Nomor 20 Tahun 2016, pemanfaatan data perseorangan harus sesuai dengan ketentuan peraturan perundang-undangan dan berisi setiap keterangan yang nyata dan benar yang melekat dan dapat diidentifikasi, baik secara langsung maupun tidak langsung.

Meski demikian, Peraturan Menteri Komunikasi dan Informatika Nomor 20 Tahun 2016 tidak memberikan penjelasan lebih detail lagi mengenai pembagian atau pengelompokkan data pribadi. Namun, merujuk pada Rancangan UndangUndang Perlindungan Data Pribadi yang diterbitkan pada April 2019, adapun pembagian jenis data pribadi terdiri atas 2 yaitu, data pribadi yang bersifat umum, dan data pribadi yang bersifat spesifik.

Dijelaskan bahwa data pribadi yang bersifat umum berarti merupakan data pribadi yang dapat diperoleh secara umum dalam akses pelayanan publik atau tercantum dalam identitas resmi. Sedangkan data pribadi yang bersifat spesifik berarti data pribadi yang bersifat sensitif terhadap keamanan dan kenyamanan kehidupan si pemilik data pribadi dan untuk memerolehnya hanya atas persetujuan dari pemilik data pribadi, pengecualian hanya bila ada ketentuan lain berdasarkan Undang-Undang. Pada dasarnya setiap konsumen sebagai pemilik data pribadi juga dapat mengajukan keluhan atau komplain dan memiliki hak agar keluhannya didengar dan segera diatasi, hal ini penting sebagai salah satu bentuk perlindungan hukum terhadap konsumen. ${ }^{14}$

14 Elvira Fitriyani Pakpahan, Legal Protection Against Depositors' Customers With Mudharabah Contract On Islamic Banks, Jurnal Pembaharuan Hukum, Vol 6, No 1, 2019, hlm., 47. 
Merujuk pada Pasal 26 Peraturan Menteri Komunikasi dan Informatika Nomor 20 Tahun 2016, adapun hak-hak yang dimiliki oleh pemilik data pribadi adalah: hak atas kerahasiaan data pribadinya, hak untuk mengajukan pengaduan kepada menteri untuk menyelesaikan sengketa data pribadi atas kerahasiaan data pribadi miliknya yang telah gagal dilindungi oleh penyelenggara sistem elektronik, berhak mengakses atau mempunyai kesempatan untuk mengubah atau memperbarui data pribadi data pribadi miliknya tanpa mengganggu sistem pengelolaann data pribadi (pengeculian hanya bila oleh peraturan perundangundangan ditentukan lain), sepanjang masih sesuai dengan ketentuan peraturan perundang-undangan maka pemilik data pribadi berhak untuk bisa mengakses atau memiliki kesempatan untuk memiliki historis data pribadinya yang pernah diserahkan kepada penyelenggara sistem elektronik, dan terakhir jika tidak ditentukan lain oleh ketentuan peraturan perundang-undangan maka pemilik data perseorangan tertentu berhak meminta pemusnahan data pribadi yang dimilikinya dalam sistem elektronik yang dikelola oleh PSE (Penyelenggara Sistem Elektronik).

Jadi, bila pemilik data pribadi merasa kerahasiaan dari data pribadinya gagal untuk dilindungi, maka pemilik data pribadi dapat mengajukan pengaduan kepada Menteri. Maksud dari pengaduan tersebut adalah sebagai upaya yang dilakukan dalam mencari penyelesaian dari suatu sengketa baik melalui musyawarah ataupun upaya penyelesaian alternatif lainnya. Adapun lebih lanjut soal tata cara pengaduan dan penanganan pengaduan, dijelaskan lebih detail pada Pasal 31 huruf a, huruf b, huruf c, huruf d, huruf e, huruf f, huruf g dan huruf h.

Akan tetapi, jika ternyata dalam upaya penyelesaian sengketa secara musyawarah atau melalui upaya penyelesaian sengketa alternatif lain masih belum bisa menyelesaikan sengketa atas kegagalan perlindungan kerahasiaan data pribadi miliknya, maka pemilik data pribadi juga bisa mengajukan gugatan berupa gugatan perdata dan diajukan sesuai ketentuan peraturan perundangundangan. Tak hanya itu, disebutkan juga pada Pasal 27 bahwa pelanggaran terhadap data pribadi dapat dikenakan beberapa sanksi administratif yaitu 
berupa: peringatan lisan, peringatan tertulis, penghentian sementara kegiatan dan pengumuman di situs dalam jaringan.

Menurut hemat penulis, ketentuan-ketentuan tersebut sebenarnya belum cukup maksimal untuk melindungi data pribadi pengguna dalam sistem elektronik, sebab hampir belum ada sanksi pidana yang betul-betul dapat memberi efek jera pada orang atau pihak yang melanggar peraturan tersebut. Sedangkan bila diperhatikan dalam Undang-Undang tentang Informasi Elektronik dan Transaksi Elektronik (UU ITE), terlihat bahwa UU ITE ini hanya sebatas menyentuh subjek perlindungan data pribadi dan tak ada ketentuan lebih lanjut tentang apa dan bagaimana detail dari pelaksanaan perlindungan data pribadi tersebut. 15

\section{Perlindungan Hukum Terhadap Data Pribadi dalam Industri Financial Technology}

Menurut Pasal 1 angka 1 Peraturan Bank Indonesia Nomor 19/12/PBI/2017 Tentang Penyelenggaraan Teknologi Finansial menyatakan, "Teknologi Finansial adalah penggunaan teknologi dalam sistem keuangan yang menghasilkan produk, layanan, teknologi, dan/atau model bisnis baru serta dapat berdampak pada stabilitas moneter, stabilitas sistem keuangan, dan/atau efisiensi, kelancaran, keamanan, dan keandalan sistem pembayaran".

Di Indonesia, Fintech yang mengalami pertumbuhan paling pesat adalah Fintech peer-to-peer lending. Pasar pembiayaan di Indonesia didominasi oleh 3 (tiga) startup peer-to-peer lending (P2PL) yaitu Modalku, Investree, Amartha dan latar belakang kenapa pertumbuhan startup P2PL atau peer-to-peer lending di Indonesia semakin tinggi adalah karena tingginya kebutuhan dana oleh masyarakat yang unbankable. ${ }^{16}$ Masyarakat yang unbankable berarti masyarakat yang belum memiliki rekening di perbankan dan di Indonesia sendiri masih

\footnotetext{
15 Setyawati Fitri Anggraeni, Polemik Pengaturan Kepemilikan Data Pribadi: Urgensi Untuk Harmonisasi dan Reformasi Hukum Di Indonesia, Jurnal Hukum \& Pembangunan, Vol 48, No. 4, 2018, hlm., 823.

16 Muhamad Rizal (et.al.), Fintech Sebagai Salah Satu Solusi Pembiayaan Bagi UMKM, Jurnal Pemikiran dan Penelitian Administrasi Bisnis dan Kewirausahaan, Vol. 3, No. 2, 2018, hlm., 98.
} 
terhitung cukup tinggi masyarakat yang unbankable. ${ }^{17}$ Sehingga, agar masyarakat unbankable yang masih di bawah piramida ekonomi bisa memiliki pengetahuan dan kesadaran tentang produk dan layanan keuangan, maka dapat dilakukan dengan meningkatkan dorongan terhadap literasi keuangan. ${ }^{18}$

Secara umum, di Indonesia sudah ada beberapa jenis Fintech yang telah berkembang, antara lain: ${ }^{19}$

1) Online payment yang fokus utamanya adalah memberikan layanan sistem pembayaran yang diselenggarakan oleh industri perbankan, seperti Sistem Kliring Nasional BI (SKNBI), BI Real Time Gross Settlement (BI-RTGS), dan BISSSS. Contoh Fintech pada sektor ini adalah Kartukku, Doku, iPaymu, dan Finnet.

2) Peer-to-peer lending merupakan Fintech yang menjadi platform pertemuan antara investor/pemberi pinjaman dan pencari pinjaman. Investor mendapat sedikit keuntungan dari dana yang akan dipinjamkan. Contoh Fintech di sektor ini adalah Modalku, Amartha, Investree, dan KoinWorks.

3) Insuretech adalah inovasi teknologi yang didesain untuk menekan penghematan dari efisiensi dari model industri asuransi. Insuretech adalah asuransi teknologi yang terinspirasi dari Fintech. Contoh perusahaan Fintech ini adalah pasarpolis.com.

4) Aggregator merupakan Fintech yang mengumpulkan dan mengolah data yang data dimanfaatkan oleh konsumen dalam pengambilan keputusan. Contoh Fintech di sektor ini adalah Cekaja, KreditGogo, Tunaiku, dan Cermati.

5) Crowdfunding adalah praktik penggalangan dana dari banyak orang untuk memodali suatu proyek atau usaha yang dilakukan melalui internet. Contoh Fintech yang berkembang adalah kitabisa.com, dan wujudkan.com.

Dengan melihat berkembangnya jenis-jenis Fintech yang ada di Indonesia, maka sangat jelas bahwa data pribadi milik konsumen/nasabah bukanlah sesuatu

17 Deni Danial Kesa, Realisasi Literasi Keuangan Masyarakat Dan Kearifan Lokal: Studi Kasus Inklusi Keuangan Di Desa Teluk Jambe Karawang Jawa Barat, Jurnal Sosial Humaniora Terapan, Vol 1, No. 2, 2019, hlm., 35.

18 Id.

19 Sri Adiningsih, Supra no. 1, hlm., 89. 
yang bisa dianggap remah dan perlu dilindungi dengan segera, mengingat sudah cukup banyak kasus-kasus hukum yang melibatkan Fintech. Khususnya mengenai kasus-kasus pelanggaran data pribadi yang melibatkan perusahaan Fintech pinjaman online. Terlebih-lebih jika perusahaan Fintech tersebut masih berstatus ilegal, belum terdaftar dan memiliki izin dari OJK (Otoritas Jasa Keuangan). ${ }^{20}$ Disinilah peran hukum sesungguhnya diperlukan oleh masyarakat. Hukum bertugas untuk menciptakan kepastian hukum karena bertujuan untuk menciptakan ketertiban dalam masyarakat. ${ }^{21}$

Fokus utama terhadap upaya perlindungan data pribadi dalam industri Fintech juga dapat dilakukan dengan:22

1) Enkripsi data yang berkaitan dengan konsumen, hal ini wajib dilakukan oleh para pelaku layanan Fintech;

2) Keamanan data milik konsumen adalah hal yang wajib dijaga para pelaku layanan Fintech;

3) Manajemen akses data merupakan hal wajib yang dilakukan para pelaku layanan Fintech;

4) Dari sisi konsumen, perlu adanya hak konsumen untuk meminta dan mendapat penjelasan dari pelaku layanan Fintech terkait penggunaan data dan informasi milik konsumen yang telah diberikan padanya.

Pada pertimbangan Peraturan Bank Indonesia Nomor 19/12/PBI/2017 tentang Penyelenggaraan Teknologi Finansial, dijelaskan bahwa peraturan ini salah satunya dibuat dengan menimbang kebutuhan masyarakat terkait dengan adanya inovasi di bidang layanan teknologi finansial. Demi peningkatan dan pengembangan dari teknologi finansial tersebut, telah diatur dalam peraturan Bank Indonesia Nomor 19/12/17, tepatnya pada Pasal 11 ayat (1) bahwa setiap

20 Tugu Jogja, “OJK Temukan 140 Fintech P2P Lending Berstatus Ilegal”, 2019, (https://kumparan.com/tugujogja/ojk-temukan-140-fintech-p2p-lending-berstatus-ilegal1rOjx95Az8h), diakses pada 15/11/2019.

21 Rai Mantili, Tanggung Jawab Renteng Ganti Rugi Kerugian Immateriil Atas Perbuatan Melawan Dihubungkan Dengan Asas Kepastian Hukum, Jurnal Bina Mulia Hukum, Vol. 4, No. 1, 2019, hlm., 109.

22 Rinitami Njatrijani, Perkembangan Regulasi Dan Pengawasan Financial Technology Di Indonesia, Diponegoro Private Law Review, Vol. 4, No. 3, 2019, hlm., 471. 
penyelenggara teknologi finansial wajib terlebih dahulu diuji coba melalui Regulatory Sandbox yang diselenggarakan oleh Bank Indonesia. Adanya Regulatory Sandbox bertujuan untuk mencegah berbagai risiko yang terdapat dalam inovasi Fintech saat produk dipasarkan, seperti: kerahasiaan nasabah, pencurian data, cyber attack dan berbagai risiko lainnya. ${ }^{23}$

Kemudian terkait dengan pelanggaran yang dilakukan oleh penyelenggara teknologi finansial, tentu terdapat sanksi yang harus diterima. Sanksi akan diterima bila penyelenggara teknologi finansial tidak mendaftar dan telah melanggar berbagai ketentuan yang telah ditentukan dalam peraturan ini. Adapun pengaturan mengenai sanksi dapat dilihat pada Pasal 20 ayat (1), Pasal 20 ayat (2) dan Pasal 20 ayat (3) Peraturan Bank Indonesia Nomor 19/12/17. Dalam Pasal-Pasal tersebut, ada beragam sanksi yang sudah diatur dan semuanya termasuk dalam sanksi administratif.

Terkait soal perlindungan data pribadi, salah satu ketentuannya diatur dalam Pasal 8 ayat (1) yang berisi kewajibannya sebagai penyelenggara teknologi finansial yang sudah terdaftar dan salah satu kewajibannya adalah menjaga kerahasiaan data dan/atau informasi konsumen, termasuk di dalamnya data dan/atau informasi transaksi. Dengan demikian, apabila kerahasiaan data dan/atau infomasi milik konsumen dilanggar, maka sanksi yang dapat diberikan kepada penyelenggara teknologi finansial adalah berupa teguran tertulis dan/atau dihapusnya penyelenggara teknologi finansial tersebut dari daftar penyelenggara teknologi yang ada di Bank Indonesia ${ }^{24}$.

Kembali pada kasus atau persoalan hukum yang sudah cukup marak terjadi pada konsumen atau nasabah Fintech P2P Lending, sebenarnya pelanggaran data pribadi dengan berbagai cara ini menjadi hal yang cukup mengkhawatirkan bagi para konsumen atau nasabah. Oleh karena itu, landasan hukum saat ini bagi

23 Priscilla D Z S (et.al.) Analisis Mekanisme Regulatory Sandbox Dalam Penyelenggaraan Teknologi Finansial Di Indonesia, Diponegoro Law Journal, Vol 8, No. 1, 2019, hlm., 646.

24 Pasal 20 ayat (2) Peraturan Bank Indonesia Nomor 19/12/PBI/2017 tentang Penyelenggaraan Teknologi Finansial. 
penyelenggaraan Fintech P2P Lending adalah POJK Nomor 77/POJK.01/2016 tentang Layanan Pinjam Meminjam Uang Berbasis Teknologi Informasi.

Layanan pinjam meminjam uang berbasis teknologi informasi ini menggunakan jaringan internet dan melalui sistem elektronik secara langsung, kemudian pihak penyelenggara jasa keuangan yang mempertemukan pemberi pinjaman dengan penerima pinjaman dalam rangka melakukan perjanjian pinjam meminjam dalam mata uang rupiah. ${ }^{25}$ Dapat diketahui bahwa perjanjian pinjam meminjam uang berbasis teknologi informasi berbeda dengan perjanjian pinjam meminjam uang biasa karena pelaksanaannya dilakukan dengan sistem elektronik dan jaringan internet atau dapat juga dikatakan sebagai proses perjanjian pinjam meminjam yang dilakukan secara online.

Tak berbeda jauh halnya dengan peraturan Bank Indonesia yang punya pengaturan mengenai penyelenggaran Fintech, ketentuan Peraturan Otoriras Jasa Keuangan Nomor 77/POJK.01/2016 (Selanjutnya disebut POJK Nomor 77/POJK.01/2016) ini juga mewajibkan penyelenggara layanan pinjam meminjam uang berbasis teknologi informasi melakukan pendaftaran dan harus mengajukan perizinan kepada Otoritas Jasa Keuangan. Hal ini dilakukan agar penyelenggara punya legalitas yang kuat dan juga merupakan salah satu tugas dari Otoritas Jasa Keuangan untuk melakukan pemeriksaan dan pengawasan terhadap penyelenggara tersebut. Cukup jelas bahwa urusan pendaftaran dan perizinan ini menjadi hal wajib yang harus dilakukan setiap penyelenggara, sebab hal ini secara langsung atau tidak langsung akan memengaruhi kredibilitas dari penyelenggara tersebut di mata para pengguna layanan pinjam meminjam berbasis teknologi informasi ini.

Dengan adanya legalitas dari penyelenggara ini, para pengguna layanan pinjam meminjam online ini dapat merasa lebih aman dan percaya terhadap pihak penyelenggara, terutama soal keamanan data pribadi milik konsumen atau nasabah. Sebab, penyelenggara yang sudah terdaftar atau mendapat izin akan lebih mudah untuk diawasi oleh Otoritas Jasa Keuangan. Walau hal ini tidak selalu

25 Pasal 1 angka 3 Peraturan Otoritas Jasa Keuangan Nomor 77/POJK.01/2016 tentang Layanan Pinjam Meminjam Uang Berbasis Teknologi Informasi. 
menjamin keamanan data pribadi konsumen atau pengguna layanan ini, namun setidaknya hal ini lebih baik daripada penyelenggara yang statusnya masih ilegal, dan tentu saja penyelenggara Fintech yang berstatus ilegal punya potensi lebih besar untuk melanggar hak-hak milik konsumen, salah satunya berkaitan dengan masalah data pribadi. Legalitas suatu badan usaha atau perusahaan adalah unsur yang terpenting, sebab untuk diakui oleh masyarakat, perlu adanya legalitas yang menjadi jati diri yang kemudian mengesahkan dan melegalkan perusahaan atau badan usaha tersebut. 26

Terkait dengan data pribadi, berdasarkan Pasal 26 POJK Nomor 77/POJK.01/2016, dapat diketahui bahwa pada dasarnya penyelenggara punya kewajiban untuk: "menjaga kerahasiaan, keutuhan dan ketersediaan data pribadi seseorang dari awal diperoleh sampai pada akhirnya dimusnahkan serta memberi pemberitahuan secara tertulis pada pemilik data pribadi bila ternyata perlindungan kerahasiaan data pribadi tersebut gagal untuk dilindungi", dan apabila penyelenggara melanggar kewajiban dalam peraturan Otoritas Jasa Keuangan (OJK) ini, maka kewenangan OJK untuk memberikan sanksi administratif yaitu berupa: 27

1) Peringatan tertulis;

2) Denda, yakni kewajiban untuk membayar sejumlah uang tertentu;

3) Pembatasan kegiatan usaha;

4) Pencabutan izin.

Dengan demikian, POJK ini sesungguhnya sudah mengatur tentang apa dan bagaimana penyelenggaran Fintech Peer to Peer Lending yang diharapkan dapat melindungi hak-hak konsumen ataupun nasabah. Hanya saja perlindungan hukum yang diberikan kepada pengguna layanan pinjam peminjam uang berbasis teknologi ini, menurut penulis masih belum dapat memberikan rasa aman dan nyaman seutuhnya pada para pengguna, sebab sanksi yang dikenakan pada

\footnotetext{
26 Rini Fitriani, Aspek Hukum Legalitas Perusahaan Atau Badan Usaha Dalam Kegiatan Bisnis, Jurnal Hukum Samudra Keadilan, Vol 12, No. 1, 2017, hlm., 145.

27 Pasal 47 Peraturan Otoritas Jasa Keuangan Nomor 77/POJK.01/2016 tentang Layanan Pinjam Meminjam Uang Berbasis Teknologi Informasi.
} 
penyelenggara masih berupa sanksi administratif yang belum tentu mampu memberikan efek jera bagi pelanggarnya.

Berdasarkan ketentuan penutup pada Pasal 51 POJK Nomor 77/POJK.01/2016, dijelaskan juga bahwa perihal lebih lanjut mengenai ketentuan layanan pinjam meminjam uang berbasis teknologi ini diatur dalam surat edaran OJK. 2 (dua) tahun kemudian sejak diterbitkannya POJK tentang pinjam meminjam uang berbasis teknologi informasi, akhirnya diterbitkanlah Surat Edaran OJK Nomor 18/SE0JK.02/17 tentang Tata Kelola dan Risiko Teknologi Informasi pada Layanan Pinjam Meminjam Uang Berbasis Teknologi Informasi. Dalam Surat Edaran OJK tersebut, lebih rinci dan jelas diatur tentang apa saja yang termasuk informasi dan data pribadi kepunyaan pengguna layanan pinjam meminjam online yang tidak boleh sembarangan atau dilarang untuk disebarkan oleh penyelenggara dan wajib mendapat perlindungan, antara lain:28

1) Data dan informasi perseorangan, yaitu seperti: nama, alamat domisili, kartu identitas (seperti: Kartu Tanda Penduduk, Paspor, Surat Izin Mengemudi), Nomor Pokok Wajib Pajak, umur dan/atau tanggal lahir, alamat surat elektronik, Internet Protocol Address, nomor rekening, nomor telepon, nama ibu kandung, nomor kartu kredit, identitas digital (biometrik), tanda tangan, riwayat pekerjaan, riwayat pendidikan, rekening koran, daftar harta kekayaan, serta data dan informasi yang terkait lainnya.

2) Data dan informasi korporasi, yaitu seperti: nama korporasi, alamat, nomor telepon, susunan dan direksi komisaris termasuk dokumen identitas berupa Kartu Tanda Penduduk, izin tinggal/Paspor, susunan pemegang saham, nomor rekening, rekening koran, daftar aset, dokumen perusahaan, serta data dan informasi yang terkait lainnya.

3) Data dan informasi publik non publik yang sifatnya material, yaitu seperti: laporan keuangan, kinerja usaha, jumlah pelanggan, keputusan manajemen, beserta data dan informasi yang terkait lainnya.

4) Data dan informasi yang terkait dengan transaksi keuangan.

28 Surat Edaran Otoritas Jasa Keuangan Nomor 18/SEOJK.02/17 tentang Tata Kelola dan Risiko Teknologi Informasi pada Layanan Pinjam Meminjam Uang Berbasis Teknologi Informasi. 
5) Data dan informasi yang terkait dengan perjanjian atau kontrak.

Pengecualian terhadap larangan untuk menyebarkan data dan informasi pribadi di atas hanya berlaku apabila penyelenggara sudah mendapat persetujuan tertulis dari pengguna dan/atau oleh peraturan perundang-undangan yang berlaku mewajibkannya, dan untuk persetujuan tertulis tersebut, penyelenggara harus bisa memastikan kalau data dan infromasi pribadi milik pengguna yang akan diberikan kepada pihak ketiga, haruslah sesuai dengan tujuan yang telah disepakati antara penyelenggara dan pihak lainnya, yang artinya data dan informasi pribadi pengguna tersebut tidak boleh diberikan selain dari tujuan yang sudah disepakati tersebut. ${ }^{29}$ Selain itu, terkait data dan informasi pengguna yang diperoleh, dimanfaatkan sampai pada akhirnya dimusnahkan harus memenuhi kriteria tertentu yang dijabarkan dalam Surat Edaran 0JK Nomor 18/SEOJK.02/17 ini. Pada dasarnya, Otoritas Jasa Keuangan punya peranan sebagai regulator, yakni peranan sebagai pengawasan dan pengaturan, yang bila dikaitkan dengan teori perlindungan hukum, peranannya sebagai pengawasan meliputi upaya preventif dan represif. 30

Berdasarkan situs resmi OJK yang memuat statistik Fintech Lending pada periode Oktober tahun 2019, berikut data dari perusahaan Fintech yang terdaftar atau berizin: ${ }^{31}$

1) Perusahaan yang sudah terdaftar/berizin berjumlah sebanyak 144 (seratus empat puluh empat).

2) 131 (seratus tiga puluh satu) di antaranya adalah perusahaan Fintech yang terdaftar dan 13 (tiga belas) lainnya adalah perusahaan Fintech yang berizin.

3) 132 (seratus tiga puluh dua) di antaranya adalah perusahaan Fintech konvensional dan 12 (dua belas) lainnya adalah perusahaan Fintech syariah.

29 Surat Edaran OJK No. 18/SEOJK.02/17 tentang Tata Kelola dan Risiko Teknologi Informasi pada Layanan Pinjam Meminjam Uang Berbasis Teknologi Informasi

30 I Wayan Bagus Pramana (et.al.), Peranan Otoritas Jasa Keuangan Dalam Mengawasi Lembaga Keuangan Non Bank Berbasis Financial Technology Jenis Peer To Peer Lending, Jurnal Kertha Semaya, Vol. 02, No. 14, 2014, hlm., 11.

31 Otoritas Jasa Keuangan, "Statistik Fintech Lending Periode Oktober 2019", 2019, (https://www.ojk.go.id/id/kanal/iknb/data-dan-statistik/fintech/Pages/Statistik-FintechLending-Periode-Oktober-2019.aspx), diakses pada 03/12/2019. 
Lalu, bila hasil statistik tersebut dibandingkan dengan laporan statistik Fintech Lending pada periode Juni tahun 2019, berikut hasilnya: ${ }^{32}$

1) Perusahaan yang sudah terdaftar/berizin berjumlah sebanyak 113 (seratus tiga belas); dan

2) 107 (seratus tujuh) di antaranya adalah perusahaan Fintech konvensional dan 6 (enam) di antaranya adalah perusahaan Fintech syariah.

Berdasarkan hasil statistik Fintech Lending pada bulan Juni 2019 dan Oktober di atas, terlihat terjadinya peningkatan yang cukup signifikan dalam waktu beberapa bulan saja, yakni bertambah sebanyak 31 (tiga puluh satu) perusahaan Fintech, dan tentu ada potensi peningkatan jumlah perusahaan Fintech lagi beberapa bulan hingga beberapa tahun kemudian. Ini artinya, industri Fintech di Indonesia punya potensi untuk terus berkembang dengan pesat. Perlu dicatat, data perusahaan Fintech di atas adalah perusahaan yang sudah terdaftar/berizin dari $0 J \mathrm{~K}$, sehingga ini berarti masih ada kemungkinan perusahaan Fintech yang sama sekali belum mendaftar dirinya atau mendapat izin dari Otoritas Jasa Keuangan, atau dengan kata lain masih berstatus ilegal. Pada dasarnya, startup Fintech punya peran yang besar, sebab jika tidak berperan besar tentu pertambahan dan kemunculannya tidak akan begitu pesat, kemunculannya juga membuat Fintech tumbuh sebagai kebutuhan yang baru bagi masyarakat. ${ }^{33}$ Hal ini bisa terjadi karena masih ada masyarakat di daerah tertentu yang tidak bisa dilayani oleh industri keuangan tradisional, yaitu perbankan yang dalam pelayanannya masih ada keterbatasan dan terikat dengan aturan yang ketat. ${ }^{34}$

Dengan demikian, data-data yang telah penulis paparkan di atas, diharapkan dapat memberikan sedikit gambaran betapa sudah berkembangnya industri Fintech di Indonesia seiring dengan berjalannya waktu. Hal ini tidak begitu mengherankan, sebab strategi untuk inklusi finansial digital telah

32 Otoritas Jasa Keuangan, "Statistik Fintech Lending Periode Juni 2019", 2019, (https://www.ojk.go.id/id/kanal/iknb/data-dan-statistik/fintech/Pages/Statistik-FintechLending-Periode-Juni-2019.aspx), diakses pada 03/12/2019.

33 Suharyati dan Pahrizal Sofyan, Edukasi Fintech Bagi Masyarakat Desa Bojong Sempu Bogor, Jurnal Bakti Masyarakat Indonesia, Vol. 1, No. 2, 2018, hlm., 4.

34 Id. hlm., 5. 
berkembang di beberapa negara seperti: Indonesia, Pakistan, Meksiko dan Bangladesh. ${ }^{35}$

Selain semua peraturan di atas, penulis berpandangan bahwa Peraturan Pemerintah terbaru yakni Peraturan Pemerintah Nomor 80 Tahun 2019, juga dapat dijadikan acuan hukum bagi para pelaku industri Fintech. Sebab, perusahaan Fintech juga menjalankan usahanya melalui sistem elektronik. Dengan adanya Peraturan Pemerintah yang mengatur perdagangan melalui sistem elektronik, industri Fintech juga diharapkan dapat berjalan dengan lebih baik dan tertib sesuai ketentuan yang telah diatur. Untuk perihal data pribadi, pada Pasal 2 huruf J Peraturan Pemerintah Nomor 80 Tahun 2019 disebutkan bahwa salah satu ruang lingkup pengaturan perdagangan melalui sistem elektronik adalah meliputi perlindungan terhadap data pribadi.

Lebih jelasnya, pada Pasal 58 \& Pasal 59 Peraturan Pemerintah Nomor 80 Tahun 2019, juga diatur tentang perlindungan terhadap data pribadi. Merujuk pada Pasal 58 Peraturan Pemerintah Nomor 80 Tahun 2019, diberlakukan bahwa setiap data pribadi sebagai hak milik pribadi dari orang atau pelaku usaha yang bersangkutan, dan setiap pelaku usaha punya kewajiban untuk bertindak sebagai pengemban amanat untuk menguasai dan menyimpan data pribadi yang sudah diperoleh sesuai dengan ketentuan yang ada dalam peraturan perundangundangan, dan dalam penjelasan Pasal 58 Peraturan Pemerintah Nomor 80 Tahun 2019, yang dimaksud dengan pengemban amanat adalah sebagai pengendali data pribadi sesuai dengan peruntukannya dan perlu diperhatikan kepatutan serta praktik bisnis yang berkembang agar sesuai dengan acuan standar perlindungan data pribadi. Sedangkan pada Pasal 59 Peraturan Pemerintah Nomor 80 Tahun 2019, juga diatur tentang kaidah perlindungan yang harus dipenuhi agar sesuai dengan kelaziman atau standar perlindungan data pribadi. Mengenai sanksi, berdasarkan Pasal 80 Peraturan Pemerintah Nomor 80 Tahun 2019 dapat dilihat bahwa para pelanggar ketentuan Pasal 58 \& Pasal 59 Peraturan

35 Douglas W. Arner, Ross P. Buckley, \& Dirk A. Zetzsche, Fintech for Financial Inclusion: A Framework for Digital Financial Transformation, University of Hong Kong Faculty of Law Legal Studies Research Paper Series, No. 2019/001, hlm., 21. 
Pemerintah Nomor 80 Tahun 2019 hanya dikenakan sanksi berupa sanksi administratif seperti: peringatan tertulis, masuk dalam daftar prioritas pengawasan dan daftar hitam, mendapat pemblokiran sementara, hingga Izin usaha yang dicabut.

\section{Analisis Kritis Terhadap Peraturan Perundang-Undangan yang Dibutuhkan Indonesia untuk Mengatur Perlindungan Data Pribadi dalam Industri Fintech}

RUU Perlindungan Data Pribadi, sejatinya merupakan ius constituendum yang diharapkan dapat menampung dan menyelesaikan persoalan data pribadi yang semakin pelik. Pertanyaan yang kemudian muncul adalah apakah Rancangan Undang-Undang tentang Perlindungan Data Pribadi bisa menjadi solusi yang tepat, khususnya dalam industri Fintech? Untuk menjawab hal ini, perlu dilihat kembali beberapa hal penting pada RUU Perlindungan Data Pribadi yang terbaru (dalam hal ini berdasarkan draf RUU Perlindungan Data Pribadi pada Desember 2019).

Pertama $_{\llcorner}$penulis berpendapat bahwa RUU Perlindungan Data Pribadi harus mampu menjawab keresahan masyarakat atas perlanggaran dan penyalahgunaan data pribadi. Salah satu contoh yang paling sering terjadi berkaitan dengan nomor telepon seluler konsumen. Untuk masalah ini, bila dicermati isi dari Pasal 3 ayat (2) Huruf e Rancangan Penjelasan Undang-Undang Perlindungan Data Pribadi, disebutkan bahwa "yang dimaksud dengan Data Pribadi yang dikombinasikan untuk mengidentifikasi seseorang antara lain nomor telepon seluler." Dengan demikian, nomor telepon seluler secara tegas merupakan data pribadi yang harus dilindungi, sebab merujuk pada Bab VIII tentang Larangan Dalam Penggunaan Data Pribadi, tepatnya pada Pasal 51 RUU tentang Perlindungan Data Pribadi berisi tentang larangan penggunaan data pribadi yang tidak sah dan melawan hukum seperti memperoleh, mengumpulkan, mengungkapkan dan menggunakan data pribadi yang bukan miliknya untuk menguntungkan diri sendiri serta merugikan pemilik data pribadi tersebut, dan ternyata sudah ada sanksi pidana yang siap menjerat siapa saja yang melanggar 
ketentuan tersebut yang sebagaimana diatur dalam Bab XIII tentang Ketentuan Pidana, yakni berupa sanksi pidana penjara dan sanksi pidana denda. Sedangkan hukum positif (ius constitutum) tentang perlindungan data pribadi masih belum mencakup sanksi pidana yang tegas, masih hanya sebatas pada sanksi perdata dan sanksi administratif.

Kedua, jika dilihat secara keseluruhan maka RUU tentang Perlindungan Data Pribadi ini pada dasarnya merupakan standar acuan umum tentang bagaimana data pribadi dapat dilindungi sesuai ketentuan perundang-undangan. Hal ini bisa dimengerti mengingat setiap sektor memiliki karakteristiknya masingmasing yang perlu disesuaikan lagi penerapannya. Meski demikian, jika dikaitkan dengan industri Fintech maka penulis berpendapat bahwa RUU Perlindungan Data Pribadi masih kurang bersifat spesifik, contohnya seperti bagaimana hukum bisa menjamin perlindungan terhadap data pribadi konsumen yang diberikan pada pihak pengelola aplikasi Fintech saat melakukan registrasi? Meski demikian, penulis bisa memaklumi hal ini sebab bagaimanapun juga industri Fintech merupakan industri yang terus berkembang pesat. Sehingga untuk bisa mencakup semua persoalan data pribadi dalam industri Fintech juga memerlukan proses dan waktu yang tidak sedikit.

Ketiga, meski nantinya RUU tentang Perlindungan Data Pribadi sudah mampu menjadi payung hukum baru dan disesuaikan bagi para pihak dalam industri Fintech, penulis berharap bahwa di masa depan nanti Pemerintah juga bisa mewujudkan Undang-Undang yang secara khusus mengatur perlindungan data pribadi dalam industri Fintech, agar persoalan data pribadi yang diatur tidak hanya bersifat umum, namun juga bersifat khusus sesuai kebutuhan perlindungan data pribadi dalam industri Fintech yang mungkin akan semakin kompleks di masa depan. Selain itu, untuk mendukung pelaksanaan Undang-Undang tersebut sangat perlu adanya pendirian lembaga yang secara khusus mengawasi perlindungan data pribadi di Indonesia, sebab praktik-praktik di dunia pun 
bahkan menunjukkan pentingnya pengawasan data pribadi melalui institusi independen. ${ }^{36}$

\section{Penutup}

Berdasarkan hasil dari penelitian dan seluruh uraian di atas, penulis dapat menarik kesimpulan bahwa perlindungan hukum terhadap data pribadi dalam industri teknologi finansial di Indonesia saat ini sudah cukup baik dengan adanya berbagai peraturan yang mendukung perlindungan terhadap data pribadi terutama data pribadi dalam industri Fintech. Namun belum bisa dikatakan maksimal untuk memberikan perlindungan hukum serta rasa aman dan nyaman bagi para konsumen atau nasabah Fintech. Alasan penulis berpendapat demikian adalah karena peraturan-peraturan tersebut masih belum dapat dikatakan lengkap dan menyeluruh. Pada UU ITE, perihal data pribadi masih dibahas secara umum dan tidak eksplisit, sedangkan untuk Peraturan Menteri Komunikasi dan Informatika Nomor 20 Tahun 2016 tidak memberikan penjelasan lebih lanjut tentang kategori dan jenis data pribadi yang dimaksud dan hanya menjelaskan tentang mekanisme pengaturan perlindungan data pribadi pada sistem eletronik. Lalu, untuk peraturan Bank Indonesia Nomor 18/40/PBI/2016 hanya membahas tentang jasa sistem pembayaran pada Fintech, demikian halnya dengan POJK Nomor 77/POJK.01/2016 hanya membahas Fintech yang berbasis layanan pinjam meminjam.

Padahal, diketahui bahwa jenis-jenis Fintech yang ada di Indonesia cukup beragam dan tak hanya berpusat pada jenis Fintech tertentu. Untuk peraturan Bank Indonesia Nomor 19/12/PBI/2017 sudah cukup spesifik mengatur tentang jenis dan penyelenggaraan Fintech di Indonesia. Demikian juga, Surat Edaran OJK Nomor 18/SE0JK.02/17 sudah memberikan penjelasan lebih rinci apa-apa saja yang termasuk dalam data pribadi dalam Fintech yang harus dilindungi. Untuk Peraturan Pemerintah Nomor 80 Tahun 2019 juga sudah turut menerapkan prinsip atau kaidah perlindungan terhadap data pribadi. Akan tetapi, hal penting

36 Wahyudi Djafar (et.al.), Perlindungan Data Pribadi di Indonesia: Usulan Pelembagaan Kebijakan dari Perspektif Hak Asasi Manusia, Lembaga Studi dan Advokasi Masyarakat (ELSAM), 2016, hlm,. 63. 
lain yang menurut penulis menjadi kelemahan dari peraturan-peraturan tersebut adalah sanksi yang diberikan masih sebatas pada penyelesaian sengketa alternatif, gugatan perdata dan sanksi administratif. Satu-satunya sanksi pidana penjara yang dapat diberikan kepada para pelanggar data pribadi hanya ada pada UU ITE bila unsur pidananya terpenuhi, itupun belum mencakup masalah data pribadi yang lebih kompleks atau masih bersifat umum.

Dengan hadirnya RUU Perlindungan Data Pribadi juga diharapkan bisa menjadi payung hukum baru bagi para pihak dalam berbagai sektor industri, termasuk industri Fintech. Namun berdasarkan hasil analisis terhadap RUU Perlindungan Data Pribadi, bisa ditarik kesimpulan bahwa meski nantinya RUU Perlindungan Data Pribadi bisa menjadi payung hukum baru, ternyata perlindungan data pribadi yang dicakup masih bersifat umum dan harus disesuaikan dengan kebutuhan masing-masing sektor industri. Padahal, bisa dikatakan bahwa kebutuhan perlindungan data pribadi dalam setiap industri akan berbeda-beda, apalagi untuk industri Fintech yang merupakan gabungan dari sektor finansial dan teknologi.

Sehingga akan lebih baik jika di waktu yang akan datang, Pemerintah bisa mewujudkan Undang-Undang yang secara khusus mengatur perlindungan data pribadi dalam industri Fintech. Catatan penting yang harus diperhatikan adalah saat sudah berlakunya Undang-Undang Perlindungan Data Pribadi, sangat perlu pembentukan lembaga khusus yang mengawasi perlindungan data pribadi di Indonesia agar bisa mendukung pelaksanaan dan penerapan regulasi terkait perlindungan data pribadi tersebut. Dengan adanya RUU Perlindungan Data Pribadi dan Peraturan Pemerintah Nomor 80 Tahun 2019 tentang Perdagangan Melalui Sistem Elektronik, menunjukkan bahwa pemerintah sampai saat ini masih terus berupaya untuk melakukan pengawasan dan pencegahan terhadap penyalahgunaan data pribadi, termasuk data pribadi dalam industri Fintech. 


\section{Daftar Pustaka}

\section{Buku:}

I Made Pasek Diantha, Metodologi Penelitian Hukum Normatif Dalam Justifikasi Teori Hukum, Prenada Media Group, Jakarta, Maret 2017.

Sinta Dewi Rosadi, Cyber Law: Aspek Data Privasi Menurut Hukum Internasional, Regional, dan Nasional, Refika Aditama, Bandung, 2015.

Sri Adiningsih, Transformasi Ekonomi Berbasis Digital di Indonesia, Gramedia Pustaka Utama, Jakarta, 2019.

Wahyudi Djafar (et.al.), Perlindungan Data Pribadi di Indonesia: Usulan Pelembagaan Kebijakan dari Perspektif Hak Asasi Manusia, Lembaga Studi dan Advokasi Masyarakat (ELSAM), 2016.

\section{Jurnal:}

Douglas W. Arner, Ross P. Buckley, \& Dirk A. Zetzsche, Fintech for Financial Inclusion: A Framework for Digital Financial Transformation, University of Hong Kong Faculty of Law Legal Studies Research Paper Series, No. $2019 / 001$.

Deni Danial Kesa, Realisasi Literasi Keuangan Masyarakat Dan Kearifan Lokal: Studi Kasus Inklusi Keuangan Di Desa Teluk Jambe Karawang Jawa Barat, Jurnal Sosial Humaniora Terapan, Vol 1, No. 2, 2019.

Elvira Fitriyani Pakpahan, Legal Protection Against Depositors' Customers With Mudharabah Contract On Islamic Banks, Jurnal Pembaharuan Hukum, Vol 6, No 1, 2019.

I Wayan Bagus Pramana (et.al.), Peranan Otoritas Jasa Keuangan Dalam Mengawasi Lembaga Keuangan Non Bank Berbasis Financial Technology Jenis Peer To Peer Lending, Jurnal Kertha Semaya, Vol. 02, No. 14, 2014.

Muhamad Rizal (et.al.), Fintech Sebagai Salah Satu Solusi Pembiayaan Bagi UMKM, Jurnal Pemikiran dan Penelitian Administrasi Bisnis dan Kewirausahaan, Vol. 3, No. 2, 2018.

Priscilla D Z S (et.al.) Analisis Mekanisme Regulatory Sandbox Dalam Penyelenggaraan Teknologi Finansial Di Indonesia, Diponegoro Law Journal, Vol 8, No. 1, 2019.

Setyawati Fitri Anggraeni, Polemik Pengaturan Kepemilikan Data Pribadi: Urgensi Untuk Harmonisasi dan Reformasi Hukum Di Indonesia, Jurnal Hukum \& Pembangunan, Vol 48, No. 4, 2018.

Sinta Dewi, Konsep Perlindungan Hukum Atas Privasi Dan Data Pribadi Dikaitkan Dengan Penggunaan Cloud Computing Di Indonesia, Yustisia Jurnal Hukum, Vol 5, No. 1, 2016.

Suharyati dan Pahrizal Sofyan, Edukasi Fintech Bagi Masyarakat Desa Bojong Sempu Bogor, Jurnal Bakti Masyarakat Indonesia, Vol. 1, No. 2, 2018.

Rai Mantili, Tanggung Jawab Renteng Ganti Rugi Kerugian Immateriil Atas Perbuatan Melawan Dihubungkan Dengan Asas Kepastian Hukum, Jurnal Bina Mulia Hukum, Vol. 4, No. 1, 2019. 
Rinitami Njatrijani, Perkembangan Regulasi Dan Pengawasan Financial Technology Di Indonesia, Diponegoro Private Law Review, Vol. 4, No. 3, 2019.

Rini Fitriani, Aspek Hukum Legalitas Perusahaan Atau Badan Usaha Dalam Kegiatan Bisnis, Jurnal Hukum Samudra Keadilan, Vol 12, No. 1, 2017.

\section{Rancangan Undang-Undang:}

Rancangan Undang-Undang Perlindungan Data Pribadi, April 2019.

Rancangan Undang-Undang Perlindungan Data Pribadi, Desember 2019.

\section{Internet:}

Aris Wasita, "OJK: industri "fintech" di Indonesia berkembang pesat", 2019, (https://www.antaranews.com/berita/1030232/ojk-industri-fintech-diindonesia-berkembang-pesat).

Hendra Friana, "Jokowi Teken PP 80/2019 tentang Perdagangan Elektronik", 2019, (https://tirto.id/jokowi-teken-pp-802019-tentang-perdaganganelektronik-emQg).

Mochamad Januar Rizki, "Ragam Masalah Hukum Fintech yang Jadi Sorotan di 2018",2018,

(https://www.hukumonline.com/berita/baca/lt5c1c9d0759592/ragammasalah-hukum-fintech-yang-jadi-sorotan-di-2018/).

Otoritas Jasa Keuangan, "Statistik Fintech Lending Periode Oktober 2019”, 2019, (https://www.ojk.go.id/id/kanal/iknb/data-danstatistik/fintech/Pages/Statistik-Fintech-Lending-Periode-Oktober2019.aspx).

Otoritas Jasa Keuangan, "Statistik Fintech Lending Periode Juni 2019", 2019, (https://www.ojk.go.id/id/kanal/iknb/data-dan statistik/fintech/Pages/Statistik-Fintech-Lending-Periode-Juni-2019.aspx).

Otoritas Jasa Keuangan, "Majalah Edukasi Konsumen Edisi Maret 2020”, 2020, (https://sikapiuangmu.ojk.go.id/FrontEnd/CMS/DetailMateri/492).

Pratiwi Agustin, "Rancangan Undang-Undang Perlindungan Data Pribadi", 2019, (https://aptika.kominfo.go.id/2019/09/rancangan-undang-undangperlindungan-data-pribadi/).

Tugu Jogja, "OJK Temukan 140 Fintech P2P Lending Berstatus Ilegal", 2019, (https://kumparan.com/tugujogja/ojk-temukan-140-fintech-p2p-lendingberstatus-ilegal-1rOjx95Az8h).

Yanurisa Ananta, "Fintech Salahgunakan Data Konsumen, Siap-siap Kena Denda", 2019,(https://www.cnbcindonesia.com/tech/20190705141712-3782978/fintech-salahgunakan-data-konsumen-siap-siap-kena-denda).

\section{Peraturan Perundang-Undangan:}

Undang-Undang Dasar Negara Republik Indonesia Tahun 1945.

Undang-Undang Republik Indonesia Nomor 8 Tahun 1999 tentang Perlindungan Konsumen.

Undang-Undang Republik Indonesia Nomor 11 tahun 2008 tentang Informasi dan Transaksi Elektronik. 
Undang-Undang Republik Indonesia Nomor 19 Tahun 2016 tentang Perubahan Atas Undang-Undang Nomor 11 Tahun 2008 tentang Informasi dan Transaksi Elektronik.

Peraturan Menteri Komunikasi dan Informatika Republik Indonesia Nomor 20 Tahun 2016 tentang Perlindungan Data Pribadi dalam Sistem Elektronik.

Peraturan Bank Indonesia Nomor 18/40/PBI/2016 tentang Penyelenggaraan Pemrosesan Transaksi Pembayaran.

Peraturan Bank Indonesia Nomor 19/12/PBI/2017 tentang Penyelenggaraan Teknologi Finansial.

Peraturan Otoritas Jasa Keuangan (POJK) Nomor 77/POJK.01/2016 tentang Layanan Pinjam Meminjam Uang Berbasis Teknologi Informasi.

Peraturan Pemerintah Republik Indonesia Nomor 82 Tahun 2012 tentang Penyelenggaraan Sistem Dan Transaksi Elektronik

Peraturan Pemerintah Republik Indonesia Nomor 80 Tahun 2019 tentang Perdagangan Melalui Sistem Elektronik.

Surat Edaran Otoritas Jasa Keuangan Nomor 18/SEOJK.02/17 tentang Tata Kelola dan Risiko Teknologi Informasi pada Layanan Pinjam Meminjam Uang Berbasis Teknologi Informasi. 